\section{JUNIOR MEMBERS ROUND TABLE}

JMRT has some exciting plans for the June conference in Chicago. We invite all ALA members who one of our projects interests to join us for fun, professional improvement, and a better ALA.

JMRT's annual orientation session will feature a press conference this year. The editors of American Libraries, Wilson Library Bulletin, Library Journal and School Library Journal have been invited to share their predictions for the conference and interview members of the ALA Executive Board and COPES. It should be an enlightening experience.

JMRT is planning the first child care facilities for an ALA conference. Professional children's consultants will be employed to care for the children during the day assisted by librarian volunteers. Infants through fourteenyear-olds will be accommodated, with trips through nearby museums for the older children. If you are interested in using the ser-

\section{APPOINTMENTS}

John N. BerRy, III, will join the Graduate School of Library and Information Sciences of the University of Pittsburgh, as visiting lecturer.

JoHN B. BLACK has accepted appointment as assistant librarian, services, at the University of Guelph, Ontario, Canada.

MICHAEL K. BUCKLAND has been announced as assistant director of libraries for technical services, and as associate professor of library science at Purdue University Libraries, Lafayette, Indiana.

Marion D. Cameron has received appointment as assistant librarian, personnel, at the University of Guelph, Ontario, Canada.

Frederick G. Cook is now university librarian, Norwich University, Northfield, Vermont.

Renee Feinberg has joined the Brooklyn College Library as reference librarian in the social science division, City University, New York.

John Fonsman has received appointments to the Graduate School of Library and Information Sciences, and as the assistant director of the Bureau of Urban Library Research, both with the University of Pittsburgh.

KENDAL FUnK is now reference librarian in vice or assisting JMRT in maintaining, contact Nancy Schimmel, San Mateo County Library, Belmont, CA 94022.

Another exciting project sponsored by JMRT is a daily convention newspaper. Reporters will attend assigned meetings and submit reports for the newspaper which will be edited and prepared each evening. ALA headquarters has generously offered its producing facilities and staff for the printing phase which will be completed each morning at the ALA headquarters. Three thousand copies will be distributed to ALA attendees daily, Sunday through Friday.

It is hoped that this newssheet will promote a better understanding of conference activities. The newssheet will communicate to the membership the events of the preceding day and a highlight of the forthcoming day's activities in an objective and factual capsulized format. Anyone interested in participating in any phase of this project should contact Catherine O'Connell, Linthicum Library, 400 Shipley Road, Linthicum, MD 21090.

\section{Personnel}

the science division at the Brooklyn College Library, City University, New York.

LoRraine GiurLani is now a cataloger on the staff of the Honnold Library of the Claremont College, California.

IRENE GODDEN is the newly appointed assistant acquisitions librarian at California State College Library, Dominguez Hills.

Norma Haimes has joined the Brooklyn College library staff as reference librarian in the humanities division, City University, New York.

Phillip R. Heen has been named an assistant professor at the University of Denver Graduate School of Librarianship, Denver, Colorado.

PaUl L. Horecky has been announced as the chief of the Slavic and Central European Division of the reference department of the Library of Congress, Washington, D.C.

David S. Hornbeck, Jr., has been appointed reference librarian in the social science library of the University of Utah Libraries.

JEANNE M. Isacco has been appointed as assistant reference librarian in the James Branch Cabell Library of the Academic Center of Virginia Commonwealth University, Richmond.

Marguerita Iskenderian has accepted the position of music cataloger in the catalog $\mathbf{d i}$ - 
vision of the Brooklyn College Library, City University, New York.

EDWApD R. Johnson has received the appointment of assistant director for Technical Operations at the Pennsylvania State University Libraries, University Park.

CuRLEY C. Jones has joined the staff of the University of Utah Libraries as reference librarian in general reference.

Oxanna Kaufman has been appointed coordinator, Undergraduate Library and $\mathrm{Hu}-$ manities and Social Science Libraries at the University of Pittsburgh, Pennsylvania.

Pauline Lybeck has been appointed serials acquisition librarian in the acquisition department of the Brooklyn College Library, City University, New York.

Debra Marsh has accepted the position as humanities bibliographer in the Honnold Library of the Claremont College, California.

MildRed Myers has been appointed librarian of the University of Pittsburgh's Graduate School of Business Library, Pennsylvania.

NaOmi G. Ogawa has joined the staff at California State College Library, Dominguez
Hills, as administrative assistant reference librarian.

Howard Pasternack has been appointed assistant editor of Library Technology Reports.

Lawrence T. Porter has been appointed assistant librarian, systems and development, at the University of Guelph, Ontario, Canada.

JANE RoBBINS has been named assistant professor at the Graduate School of Library and Information Sciences at the University of Pittsburgh.

Thomas M. Schmid has been named division head of acquisitions in the University of Utah Libraries.

Roderick G. Swartz has accepted the position of deputy director of the National Commission on Libraries and Information Sciences, Washington, D.C.

SUSAN VAUGHN has accepted appointment as reference librarian in the social science division of the Brooklyn College Library, City University, New York.

EdWARd N. Waters has been named chief of music division, Library of Congress, Washington, D.C.

\section{Classified Advertising}

NOrICE
Respondents to advertisers offering faculty
"rank" and "stafus" are advised that these terms
are ambiguous and should inquire as to benefits
involved.
All advertisements submitted by institutions
offering positions must include a salary range.
The range should provide the applicant with an
indication of the salary the institution is willing
to provide for the position offered.
All advertisements lor the Positions Wanted
and the Positions Open classifications will be ed-
ited to exclude direct or indirect references to
race, creed, color, age, and sex as conditions of
employment.

Classified advertising orders and copy, and cancellations, should be addressed to the Advertising Department, 50 East Huron Street, Chicago 6061l, and should reach that office before the second of the month preceding publication of issue desired. Copy received after that time may be held for the next issue.

Rate for classified advertising is \$1.25 per printed line. No additional charge is made for nonmember advertising.

\section{POSITIONS WANTED}

LIBRARIAN (HEAD), teacher of librarianship, or bibliographer (social sciences and business). One of the above positions is being sought by author of books, experienced teacher (both graduate and undergraduate levels), former head librarian, subject specialist (socia) sciences and business), and head of technical services. His academic background includes MLS, MA in social sciences and education, doctorate in law and equivalent of Ph.D. in economics, including knowledge of several languages. Write Dr. Jacob Shumelda, Dept. of Library Science, Northern Illinois University, DeKalb, IL 60115.

Do you need a GOOD LIBRARIAN? Experience in reference, government documents, bibliography. Broad background includes history of natural science. Subject specialties in social sciences and art. Write Julian Grossman, 515 North 22 St., Allentown, PA 18104.

\section{POSITIONS OPEN}

\section{Administration}

HEAD, PRECATALOG DEPARTMENT, responsible for or ganization and supervision of searching ordering, and receiving of library materials. Minimum requirements: MLS, knowledge of I foreign language, 5 years' professional experience in technical services with 2 years in an acquisitions department of a medium or large size academic library. Salary $\$ 12,000$ or higher depending on qualifications. Apply to Jane Titus Pers. Ln. Paley Li brary, Temple University, Philadelphia, PA I9/22.

HEAD LIBRARIAN. University of Manitoba's new science library, opening August 1972. Responsible for book selection public services staff of 5-6. Position now open. Qualifications: recognized library science degree, relevant library experience. Salary $\$ 12,000$. Usual benefits. Resume, references to Associate Director (Public Services), Elizabeth Dafoe Library, University of Manitoba, Winnipeg, Canada.

POSITION OPEN, administration. Systems librarian/assistant director. University of Arkansas af Little Rock. $\$ 10,000-\$ 12,000$ first fiscal year. Faculty rank appropriate $\$ 10,000-\$ 12,000$ first fiscal year. Faculty rank appropriate
to credentials. To conduct studies on total range of operations and design new systems. Must have recent full-time experience in college library, aptitude for mathematics, industrial engineering or business administration. Fifth-year degree in library science. Additional education desirable. Month vacation, usual benefits. Write James A. Allen, Dir. UALR Library, 33 and University Ave., Little Rock, AR 72204 .

HEAD OF READERS SERVICES. Northern Illinois University an equal opportunity employer is searching for an experienced librarian with creative imagination and enough flexibility to guide and supervise the following public service areas: circulation (including reserve, shelving, stack control and guards); general and subject reference lincluding interlibrary loan and periodicals services): government documents, archives, Faraday Science Library, map library, Southeast Asia collection, and special collections including rare books and manuscripts; and the Division of Undergraduate Services (including the general education library, the educational materials center, the Fouser Music Room library orientation and the Lorada Taft Field Campus Instructional Materials Center). 